\title{
Pollen spectrum and physico-chemical attributes of heather (Erica sp.) honeys of north Portugal
}

\author{
José Pires, ${ }^{a}$ María Letícia Estevinho, ${ }^{b}$ Xesús Feás, ${ }^{c *}$ Jesús Cantalapiedra ${ }^{d}$ \\ and Antonio Iglesias ${ }^{\mathrm{d}}$
}

\begin{abstract}
BACKGROUND: Honey legislation has been addressed to establish the minimum marketing level of the product and the need for consumer protection through correct denominations. Research oriented toward assessment of floral origin and physicochemical properties may increase the commercial value of these products. The characteristics of 23 unifloral honeys of Erica sp., from Portugal, were studied. Pollen features and some physicochemical parameters (moisture, ash, pH, free acidity, electrical conductivity, hydroxymethylfurfural content, apparent sucrose, reducing sugars and diastase activity) were determined.

RESULTS: All honey samples can be classified as monofloral Erica sp., they gave a mean value of $56 \%$ of Erica pollen type. The families Fabaceae and Rosaceae provided the greatest number of pollen types with 8 and 4 pollen types each respectively. The second most important pollen type is Eucalyptus, present in $69.6 \%$ of the samples. All honey samples met the international physicochemical quality standards. The present study found a linear correlation $(R=0.996)$ between the ash content of honeys and their specific conductivity.
\end{abstract}

CONCLUSION: All honey samples can be classified as monofloral Erica sp. Unifloral honeys are increasingly requested and appreciated, despite their higher prices. The samples were found to meet all major international honey specifications.

(c) 2009 Society of Chemical Industry

Keywords: honey; melissopalynology; physico-chemical analysis; Erica sp

\section{INTRODUCTION}

Honey is the natural, sweet substance produced by honeybees from the nectar of blossoms or from the secretion of living parts of plants or excretions of plant sucking insects on the living parts of plants. Honeybees collect, transform and combine this with specific substances of their own, and then store it and leave it in the honey comb to ripen and mature. ${ }^{1}$

Bee honey is made up of water and sugars, with other minor components such as proteins, free amino acids, flavours, aromas, pigments, vitamins and many volatile compounds. Variations in nectar content, together with other factors such as climatic conditions, soil type, and beekeeper activities contribute to the existence of different types of honey. ${ }^{2}$ Differences in their composition cause differences in the organoleptic and nutritional properties of these honeys. ${ }^{3}$

The beneficial characteristics of honey are its high nutritional value and the fast absorption of its carbohydrates on consumption. ${ }^{4}$ Furthermore, honey has a number of properties that are believed to facilitate the healing process. Honey was found to be a suitable alternative for healing wounds, burns and various skin conditions $s^{5-9}$ and also to have a potential role in cancer care. ${ }^{10}$

The major consumers and importers of honey are the industrialised countries. An increase in consumption over the last few years can be attributed to the general increase in living standards and a higher interest in natural and beneficial health products. ${ }^{11}$ Honey is a highly valuable ingredient in sauces, dressings, condiments, beverages and sweet and sour manufactured foods. ${ }^{12}$

Monofloral honeys, originating predominantly from a single botanical source, are in higher demand from the consumer, which means that they also have a higher commercial value for the producers. Therefore, the characterisation of honeys is necessary in order to better our response to consumer demands. ${ }^{13-15}$

Organoleptical properties, physico-chemical attributes and pollen spectrum are the main criteria for honey classification. ${ }^{2}$ It is

\footnotetext{
* Correspondence to: Xesús Feás, Department of Analytical Chemistry, Nutrition and Bromatology, Campus Lugo, University of Santiago de Compostela E-27002, Lugo, Galicia, Spain.E-mail:xesusfeas@gmail.com

a Escola Superior Ágraria de Ponte de Lima/Instituto Politécnico de Viana do Castelo, E-4990-706 Ponte de Lima, Portugal

b Escola Superior Agrária de Bragança/Instituto Politécnico de Bragança, E 5300, Bragança, Portugal

c Department of Analytical Chemistry, Nutrition and Bromatology, Lugo Campus, University of Santiago de Compostela, E-27002, Lugo, Galicia, Spain

d Department of Anatomyand AnimalProduction, Faculty of VeterinaryMedicine, University of Santiago de Compostela, E-27002, Lugo, Galicia, Spain
} 
comparatively simple to measure them and they provide a good information value. The physico-chemical parameters of natural honeys, such as moisture, diastase, sugars and hydroxymethylfurfural (HMF) contents, acidity and specific conductivity, are strictly defined and constitute the quality indicators which characterise individual honey varieties. ${ }^{16-19}$ The identification and quantification of pollen grains in honey sediment is the reference method used to determine the botanical origin of honey sample honeys. Usually, honeys are nominated as monofloral when at least $45 \%$ of pollen grain comes from the plant considered. For honey samples having under-represented pollen grains, (i.e. Rosmarinus, Citrus, Thymus, Arbutus and Lavandula), botanical classification may be achieved with a pollen frequency percentage of only $10-20 \%$. However, for honey samples having over-represented pollen grains, (i.e. Eucalyptus, Castanea, Cynoglossum and Myosotis) botanical origin may be achieved with a pollen frequency percentage of $70-90 \%$.

Portuguese apiculture has been practised traditionally by professional and semi-professional producers, many of whom migrate with their hives in order to take advantage of the different flowering periods. ${ }^{20}$ In 1992, the European Union (EU) created a system known as Protected Designation of Origin (PDO), to promote and protect names of quality agricultural products and foodstuffs. ${ }^{21}$ Currently, in the EU, Portugal has the highest number of honeys bearing the PDO logo, which are produced, processed and prepared in a given geographical area using certified expertise, namely: 'Mel da Serra de Lousã', 'Mel do Parque de Montezinho', 'Mel do Ribatejo Norte', 'Mel das Terras Altas do Minho', 'Mel da Terra Quente', 'Mel da Serra de Monchique', 'Mel do Alentejo', 'Mel dos Açores' and 'Mel de Barroso'. ${ }^{22}$

Heather honey is produced in Portugal from Erica sp., while in Spain and France it comes from either Calluna or Erica sp. This honey is characterised by its dark brown colour, strong flavour and a slightly salty taste. Consumers in Portugal prefer heather honeys and they are generally more costly than others. ${ }^{23,24}$

The purpose of this study was to investigate some properties of various honey samples collected from the north region of Portugal by using different honey analysis tests such as moisture, ash, $\mathrm{pH}$, free acidity, electrical conductivity, hydroxymethylfurfural (HMF) content, apparent sucrose, reducing sugars and diastase activity. The determination of the frequency of pollen grains classes, were also determined in these honey samples, in order to verify the monofloral Erica sp. origin and to obtain a complete pollen spectrum.

\section{MATERIALS AND METHODS Honey sampling}

Twenty-three typical honey samples, from Apis mellifera, were collected by beekeepers from different apiaries. The samples were from 14 localities of six districts in north Portugal. Figure 1 shows the geographical origin and identification code of the honey samples studied. All honey samples showed no sign of fermentation or granulation. They were obtained by centrifugation and stored at $5{ }^{\circ} \mathrm{C}$ until analysis, which occurred no more than 1 month after the extraction from the hives by beekeepers.

\section{Sample floral-type identification}

Even though the beekeepers themselves, according to the best of their knowledge and the location of hives, declared honey as monofloral heather honey, all the samples were subjected to qualitative pollen analysis as per Erdtman's acetolysis method. ${ }^{25}$
The aim of that analysis was to confirm that analysed samples could be declared as heather monofloral honey.

Briefly, pollen analyses are based on the extraction of pollen grains from $10 \mathrm{~g}$ of crude honey. The sample was dissolved in distilled water and the sediment is concentrated by repeated centrifuging. About $10 \mathrm{~mL}$ of acetolysis mixture $\left(\mathrm{Ac}_{2} \mathrm{O} / \mathrm{H}_{2} \mathrm{SO}_{4}\right.$, $9: 1)$ is added and the tubes are incubated in a water bath $\left(100^{\circ} \mathrm{C}\right.$ for $3 \mathrm{~min}$ ), stirred vigorously, then centrifuged and decanted. About $12 \mathrm{~mL}$ of water-free acetic acid is added, stirred thoroughly, centrifuged, and decanted. The precipitate is washed in about $12 \mathrm{~mL}$ of distilled water, centrifuged, and decanted. $12 \mathrm{~mL}$ of $7 \%$ $\mathrm{KOH}$ is added, stirred thoroughly, centrifuged and decanted.

After this, pollen grains were stained with a solution of basic fuchsin and mixed with glycerin. The examination of the pollen slides were carried out with an optical microscope at $\times 400$ and $\times 1000$ in order to make sound identification of the pollen types. A minimum of 1000 pollen grains was counted per sample. In order to recognise the pollen types, we used the reference collection of the University of Santiago de Compostela's Pharmacy Faculty, different pollen morphology guides, and information from different websites.

\section{Physicochemical analysis}

Physicochemical parameters were analysed using the Official Methods of Analysis of the Association of Official Analytical Chemists $(A O A C)^{26}$ and The Harmonised Methods of the European Honey Commission. ${ }^{27}$ Samples were analysed using the same methods during the same time period to ensure uniform conditions and comparability.

\section{Moisture}

The determination of water contents (moisture) were ascertained by refractometry, using an Abbe refractometer (Digital refractometer, Atoga, Germany). The refractometer was calibrated with distilled water before use. All measurements were performed at $20^{\circ} \mathrm{C}$. After waiting for $6 \mathrm{~min}$ for equilibration, and with the refractive index obtained, the conversion to the corresponding $\%$ moisture ( $\mathrm{g}$ water $100 \mathrm{~g}^{-1}$ honey) by means of the Chataway table was carried out. ${ }^{28}$

\section{Ash content}

The ash content was determined by sample calcination at $550{ }^{\circ} \mathrm{C}$, in a electric laboratory furnace SNOL 8.2/1100-1 (AB 'Umega', Utena, Lithuania) and calculated from the equation

$$
\operatorname{ash}(\%)=\frac{m_{1}-m_{2}}{m_{0}} \times 100
$$

where $m_{1}$ is the mass of dish and ash, $m_{2}$ the mass of platinum dish prior to calcination and $m_{0}$ is the mass of the honey taken.

\section{Electrical conductivity}

Electrical conductivity of a honey solution at $20 \%(\mathrm{w} / \mathrm{v})$ (dry matter basis) in $\mathrm{CO}_{2}$-free deionised distilled water was measured at $20^{\circ} \mathrm{C}$ in a Crison 522 conductimeter Crison, from Barcelona (Catalunya, Spain). Results were expressed as millisiemens per centimetre ( $\mathrm{mS}$ $\left.\mathrm{cm}^{-1}\right)$. 


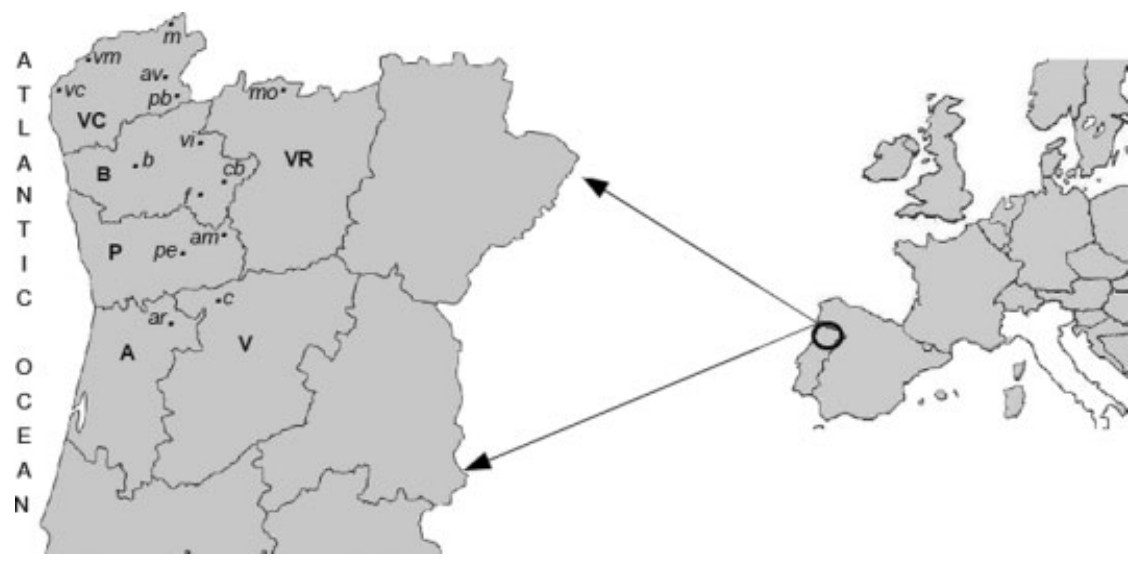

\begin{tabular}{|c|c|c|}
\hline District & Locality & Identification \\
\hline Aveiro (A) & Arouca (ar) & $1,2,3$ \\
\hline \multirow{3}{*}{ Braga (B) } & Braga (b) & 12 \\
\cline { 2 - 3 } & Cabeceiras de Basto (cb) & 10,11 \\
\cline { 2 - 3 } & Fafe (f) & $7,8,9$ \\
\cline { 2 - 3 } & Vieira do Minho (vi) & $4,5,6$ \\
\hline \multirow{2}{*}{ Porto (P) } & Amarante (am) & 13,14 \\
\hline \multirow{2}{*}{ Viseu (V) } & Penafiel (pe) & 15 \\
\hline \multirow{4}{*}{ Viana do Castelo (VC) } & Cinfaes (c) & 22 \\
\cline { 2 - 3 } & Arcos de Valdevez (av) & 20 \\
\cline { 2 - 3 } & Ponte da Barca (pb) & 16 \\
\cline { 2 - 3 } & Vila Nova de Cerveira (vc) & 17,18 \\
\cline { 2 - 3 } & Valença do Minho (vm) & 21 \\
\hline Vila real (VR) & Montalegre (mo) & 23 \\
\hline \hline
\end{tabular}

Figure 1. Map of Portugal showing honey sampling regions and distribution of the honey samples studied $(n=23)$.

pH and free acidity

Five grams of honey samples were diluted with $20 \mathrm{~mL}$ of distilled water and mixed thoroughly. The $\mathrm{pH}$ values for these samples were measured using a Digital pH Meter (pH-526 WTW, Weilheim, Germany). Free acidity was determined as follows by the titrimetric method: $10 \mathrm{~g}$ honey samples were dissolved in $75 \mathrm{~mL}$ of $\mathrm{CO}_{2}$-free water in a $250 \mathrm{~mL}$ beaker. The electrode of the $\mathrm{pH}$ meter was immersed in the solution, stirred with a magnetic stirrer and titrated to $\mathrm{pH} 8.50$ by adding $0.05 \mathrm{~mol} \mathrm{~L}^{-1} \mathrm{NaOH}$ solution.

\section{Determination of hydroxymethylfurfural}

Hydroxymethylfurfural was determined by the standard method. In brief, $5 \mathrm{~g}$ of each honey sample were transferred to a $50 \mathrm{~mL}$ volumetric flask with a total of $25 \mathrm{~mL}$ of distilled water. After clarifying samples with $500 \mu \mathrm{L}$ of Carrez reagents (I and II), samples were diluted to $100 \mathrm{~mL}$ with water. If necessary, alcohol may be added to suppress surface foam. With a clarified honey solution containing $0.2 \%(\mathrm{w} / \mathrm{v})$ sodium bisulfite as a reference and a similar solution without bisulfite as a sample, a difference spectrum was obtained which represented only the HMF in the sample, without the interfering absorption of the honey. Absorbance was determined at 284 and $336 \mathrm{~nm}$ in a $1 \mathrm{~cm}$ quartz cuvette in a Perkin Elmer Luminescence Spectrophotometer (Norwalk, CT, USA).
HMF contents, expressed as $\mathrm{mg} \mathrm{kg}^{-1}$, were calculated from the equation

$$
\mathrm{HMF}=\left(A_{284}-A_{236}\right) \times F
$$

where $A_{284}$ and $A_{236}$ are the absorbance readings, and $F\left(\mathrm{mg} \mathrm{kg}^{-1}\right)$ is 149.7 was calculated with the equation

$$
F=\frac{126 \times 1000 \times 1000}{16830 \times 10 \times 5}
$$

where 126 is the molecular weight of HMF; 16830 is the molar absorptivity of HMF at $284 \mathrm{~nm} ; 1000=\mathrm{mg} \mathrm{g}^{-1} ; 10=\mathrm{cL} \mathrm{L}^{-1} ; 1000$ $=\mathrm{g} \mathrm{kg}^{-1}$ and $5=\mathrm{g}$ of honey.

\section{Diastase activity}

Diastase activity was determined using a buffered solution of soluble starch and honey incubated in a thermostatic bath at $40^{\circ} \mathrm{C}$. Thereafter, a $1 \mathrm{~mL}$ aliquot was removed at 5-min intervals and the absorption of the sample was followed at $660 \mathrm{~nm}$ in a Perkin Elmer luminescence spectrophotometer. The diastase number was calculated using the same time taken for the absorbance to reach 0.235 , and the results were expressed in Gothe degrees as the amount $(\mathrm{mL})$ of $1 \%$ starch hydrolysed by an enzyme in $1 \mathrm{~g}$ of honey in $1 \mathrm{~h}$. 


\section{Reducing sugars and apparent sucrose}

Reducing sugars were determined by reducing Soxhlet's modification of Fehling's solution by titration at boiling point against a solution of reducing sugars in honey using methylene blue as an internal indicator. The difference in concentrations of invert sugar before and after the hydrolysis procedure (inversion) was multiplied by 0.95 to reach the apparent sucrose content.

\section{RESULTS AND DISCUSSION}

\section{Pollen analysis}

The microscopic examination confirmed the identity of the honey source indicated by the beekeepers. All honey samples can be classified as monofloral Erica sp. Figure 2 shows the total pollen types identified and the \% of Erica sp. pollen in each of the samples. Monofloral status generally refers to the presence of a single pollen type in quantities greater than $45 \%$ of the total pollen content in the spectrum. The number of Erica sp. pollen per sample varies between $45 \%$ (sample 15) and $71 \%$ (sample 3 ), the mean value being $56 \%$ with a standard deviation of $9 \%$. The Portuguese heather honeys analysed have between five and eight pollen types, the mean number being 5.8. As we can see in Fig. 2, sample 12 showed eight pollen types, the highest value for all honey samples, and a $50 \%$ Erica pollen content.

Table 1 shows the frequency of occurrence of the 22 pollen types identified in the 23 samples. The Fabaceae and Rosaceae families provided the greatest number of pollen types with eight and four pollen types each, respectively. The second most important pollen type is Rubus, present in $73.91 \%$ of the samples with a maximum value of $26 \%$ in sample 22 and minimum value of $4 \%$ in samples 6 and 12 . Next, the Eucalyptus pollen is present in $69.6 \%$ of the samples with a maximum value of $25 \%$ in sample 6 and minimum value of $6 \%$ in sample 18 . Trifolium pollen is present in $60.86 \%$ of the samples. Bees forage different plants; thus, honey is always a mixture of different sources. However, in food control, pollen analysis is very efficient for the differentiation of honeys produced in distinctly different geographical and climatic areas. ${ }^{2}$

\section{Physico-chemical parameters}

Table 2 shows the results obtained from physico-chemical analysis of the honey samples. The moisture content (\%) varied from 17.00 to 18.10 (mean value \pm standard deviation $=17.59 \pm 0.37 \%$ ). In Codex Alimentarius Standard and EU Council directives, ${ }^{1,29}$ the maximum water content value of pure floral honey is given as $23 \%$ for heather (Calluna) honeys and not more than $20 \%$ in general. The maximum amount of water present in honey is regulated for safety against fermentation, and is the only composition criteria, which as a part of the Honey Standard has to be met for all world trade honeys. Furthermore, the water content is also of great importance because it is considered to be a useful parameter for describing moistness and viscosity of honey. The water content of honey depends on various factors, for example the harvesting season, the degree of maturity reached in the hive and environmental factors. ${ }^{30}$ The small variation observed in

\section{Number of pollen types}

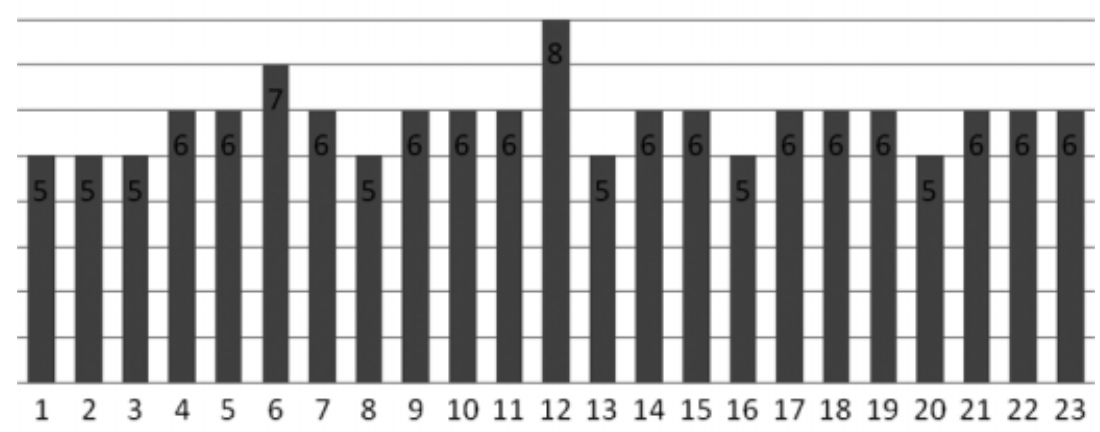

(\%) on Erica sp. pollen content

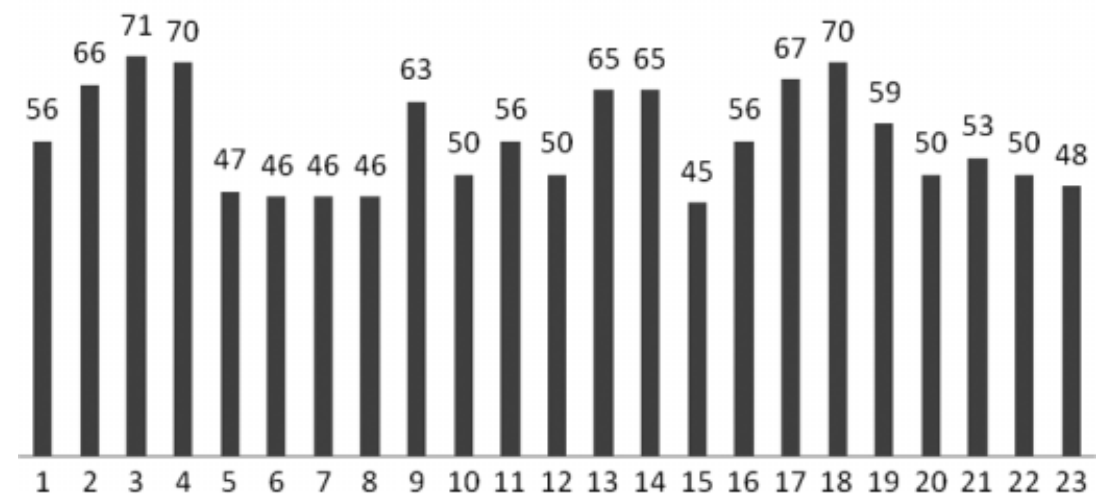

Figure 2. Graphs of the total number of pollen types and \% of Erica sp. pollen in honey samples. 


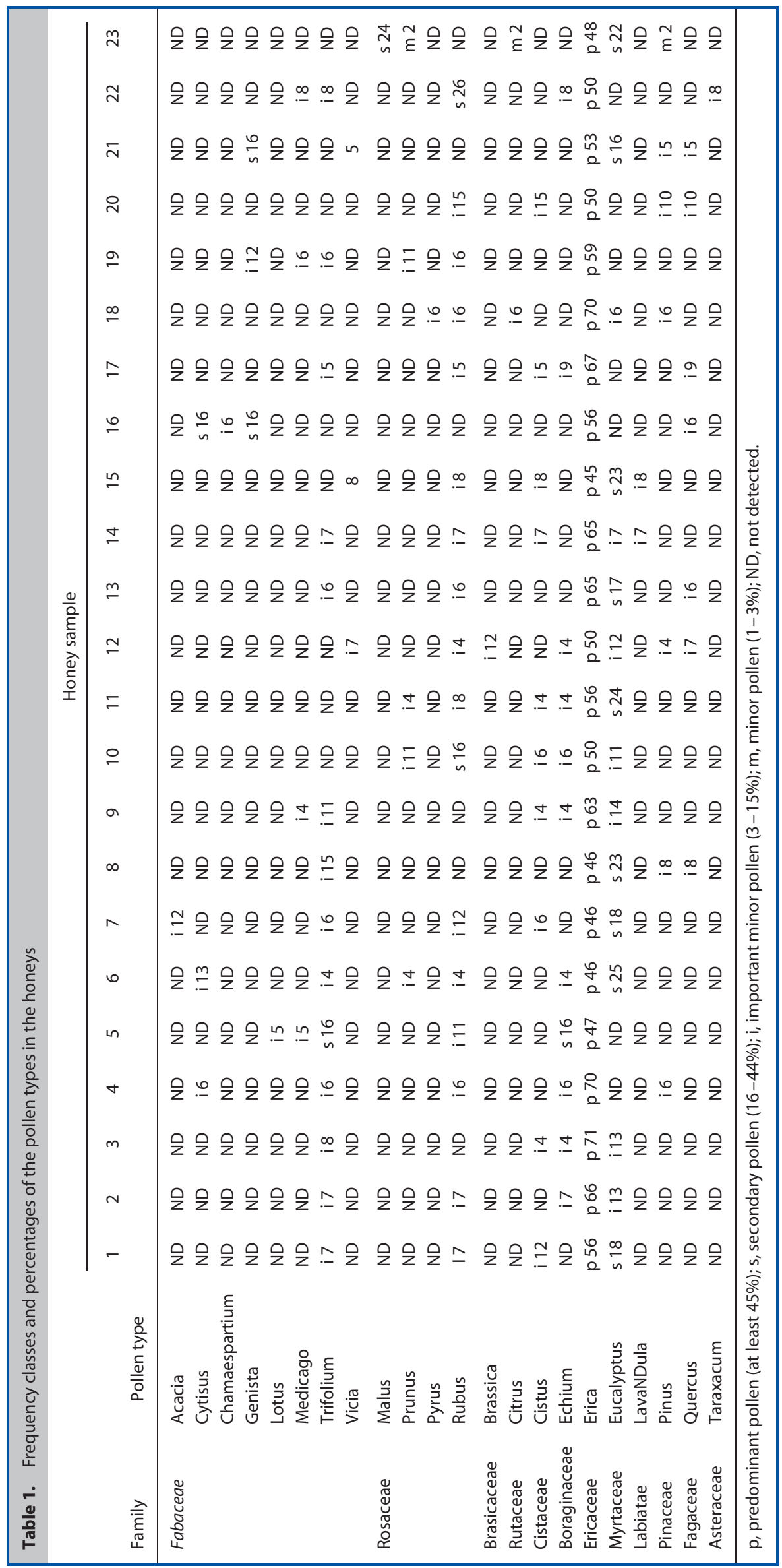




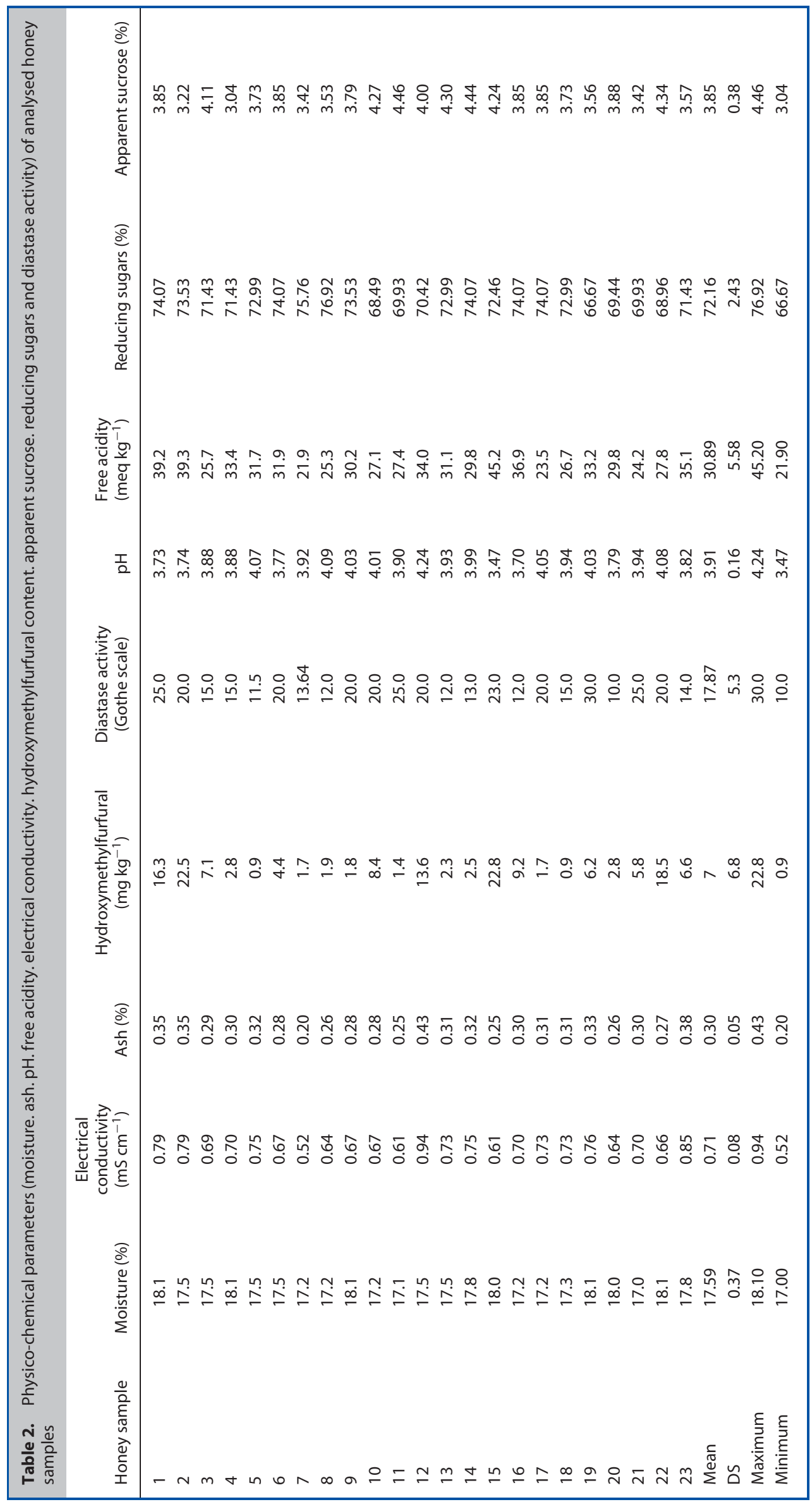


the water contents of these samples may be due to the similar beehive handling practices applied by Portuguese beekeepers. Many national beekeeping organisations have moisture content maximum values of $17.5-18.5 \%$ for special classes of quality honey. ${ }^{31}$ The samples analysed in the present work reach this quality parameter.

Ash values were below $0.60 \%$, as expected for nectar honeys (EU and Codex Standards). 1,22 The honeys considered in this study had ash contents ranging from 0.20 to 0.43 . The ash mass fraction is a useful parameter in determining botanical origin of honey and differentiating between nectar honey and honeydew.

The electrical conductivity values of the honeys analysed ranged from 0.52 to $0.94 \mathrm{mS} \mathrm{cm}^{-1}$ (mean value \pm standard deviation $=0.71 \pm 0.08 \mathrm{mS} \mathrm{cm}^{-1}$ ). The electrical conductivity of honey may be explained by taking into account the ash and acid content of honey, which reflects the presence of ions and organic acids; the higher their content, the higher the resulting conductivity. The relation between electrical conductivity and ash content has been demonstrated by many researchers, who have been determined that the above-mentioned parameters are related. ${ }^{32-34}$ The present study found a linear correlation $(R=0.996)$ between the specific conductivity of honeys and their ash content. The final regression model $(y=a x+b)$, as presented in Fig. 3, between the ash fraction and electrical conductivity $(y=1.806 x+0.164)$ differs from the one proposed by the International Honey Commission (IHC): $y=1.74 x+0.14$, where $y$ is the electrical conductivity in $\mathrm{mS} \mathrm{cm}-1$ and ash is the ash mass fraction in $\mathrm{g}$ per $100 \mathrm{~g}^{27}$ The slope differs, but the section part of the relation formula does not vary as much. As an illustration, if a sample of Portuguese heather honey has an electrical conductivity of 1 , the ash mash fraction is $0.46 \mathrm{~g}$ per $100 \mathrm{~g}$ as calculated by the obtained model, or $0.49 \mathrm{~g}$ per $100 \mathrm{~g}$ using the model proposed by the IHC. However, no statistically significant differences between models for different types of honey have been found in previous work. ${ }^{33}$ The linear regression model of ash mass fraction and electrical conductivity is therefore independent of honey type.

Diastase activity and hydroxymethylfurfural (HMF) are parameters widely recognised for the evaluation of honey freshness and/or overheating. International regulations set a minimum value of 8 on Gothe's scale for diastase activity, and a maximum HMF con-

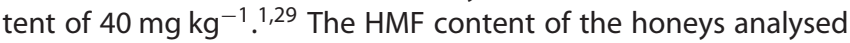
ranged from 0.9 to $22.8 \mathrm{mg} \mathrm{kg}^{-1}$ (mean value \pm standard deviation $=7.0 \pm 6.8 \mathrm{mg} \mathrm{kg}^{-1}$ ). The HMF content is indicative of honey freshness, ${ }^{35}$ and from this point of view most of the analysed samples are fresh, and thus, parallel the information provided by the producers. The diastase activity of honey samples is 17.87 (Gothe

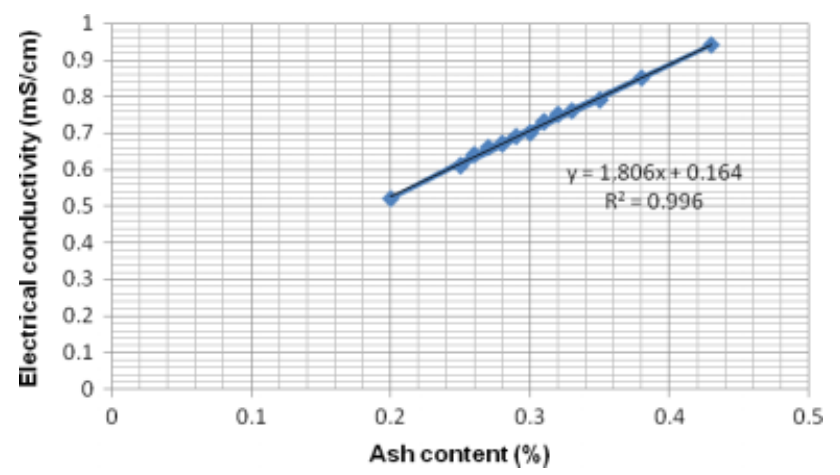

Figure 3. Linear regression between ash content and electrical conductivity in 23 Erica sp. honey samples from Portugal. degrees) (average) with a range of 10.00-30.00 and a standard deviation of 5.30 (Gothe degrees). In honey, HMF content is related to its quality and heat processing. Furthermore diastase activity has been related to the origin of the samples. ${ }^{36,37}$ No sample exceeded the limits established for these variables. Considering that honey samples were collected during the same period, differences in HMF could be attributed to the variation in climatic conditions in the area.

The honey samples presented a pH from 3.47 to 4.24 , with an average of 3.91. The low $\mathrm{pH}$ of honey inhibits the presence and growth of micro-organisms and makes honey compatible with many food products in terms of $\mathrm{pH}$ and acidity. This parameter is of great importance during the extraction and storage of honey as it influences the texture, stability and shelf life of honey. ${ }^{38}$ Published reports indicate that $\mathrm{pH}$ should be between 3.2 and 4.5. ${ }^{17,31}$ The values of $\mathrm{pH}$ in honey help to determine its origin: flower or forest; the latter shows higher values.

The free acidity of honey samples is $30.98 \mathrm{meq} \mathrm{kg}^{-1}$ (average) with a range of 21.90-45.20 and a standard deviation of $5.58 \mathrm{meq}$ $\mathrm{kg}^{-1}$. Variation in free acidity among different honeys can be attributed to floral origin ${ }^{39}$ or to variation because of the harvest season. ${ }^{14}$ The free acidity of honey may be explained by taking into account the presence of organic acids in equilibrium with their corresponding lactones, or internal esters, and some inorganic ions, such as phosphate. ${ }^{40}$ All of the investigated samples met the demands imposed by the regulations, which require in general not more than 50 meq kg ${ }^{-1}$ and not more than 80 meq kg-1 (baker's honey). ${ }^{29}$

Honey is mainly composed of the monosaccharides glucose and fructose. The content (\%) of reducing sugars in the honeys analysed ranged from 66.77 to $76.92 \%$ (mean value \pm standard deviation $=72.10 \pm 2.43$ ) and the mean percentages of apparent sucrose (\%) is $3.85 \%$ with a range of $3.04-4.46$ and a standard deviation of 0.38 (sucrose content by European Directives must be under 5\%). These two parameters confirm that the honey samples studied were floral honeys and had a good maturation grade.

Table 3 shows the physico-chemical parameters reported in literature for heather honey samples. As can be seen, the values recorded were similar to those obtained for heather honeys collected in Portugal ${ }^{23}$, Spain ${ }^{41}$ and Europe in general. ${ }^{37}$

\section{CONCLUSIONS}

In this work, melissopalinological analysis and the principal physicochemical parameters have been determined to characterise monofloral heather (Erica sp.) honey from north Portugal. All honey samples can be classified as monofloral Erica sp; they gave a mean value of $56 \%$ of Erica pollen type. The families Fabaceae and Rosaceae families provided the greatest number of pollen types with eight and four pollen types each respectively. An overall consideration of the samples analysed shows that the most important nectariferous taxa for the area studied are Rubus, Eucalyptus and Trifolium pollen types, present in $73.91 \%, 69.6 \%$ and $60.86 \%$, respectively. All of the values obtained for the physico-chemical parameters analysed in this work fell within the maximum limits defined under current Standard Codex and European legislation. The present study found a linear correlation $(R=0.996)$ between the specific conductivity of honeys and their ash content. The regression model between the ash fraction and electrical conductivity was $y=1.806 x+0.164$. From the economical standpoint, the assessment of a monofloral origin may increase the commercial value of these honeys. 


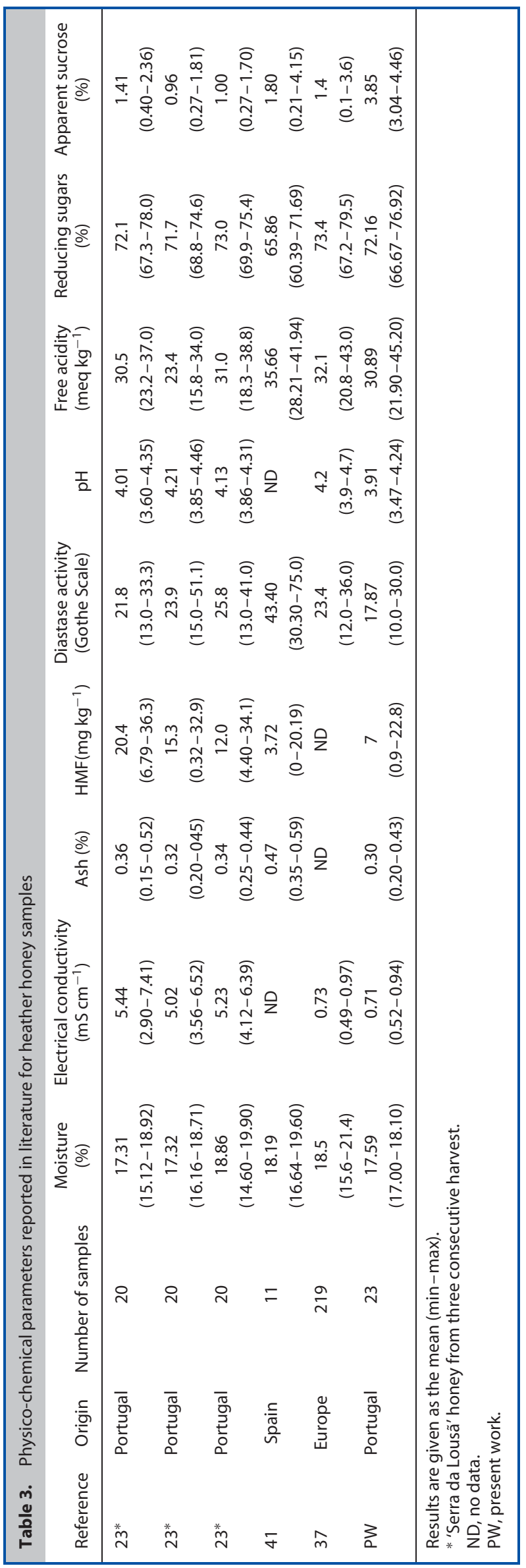




\section{ACKNOWLEDGEMENTS}

We would like to thank the Portuguese beekeepers who kindly supplied us with the honeys for this study. Xesús Feás would also like to thank the Spanish Ministerio de Ciencia e Innovación (José Castillejo program for young researchers, grant $\mathrm{n}^{\circ}$ : JC2008-00118) and Blanca Lijó for preparing the figures of the text, and to JoDee Anderson for the linguistic support she provided.

\section{REFERENCES}

1 Codex Alimentarius Commision. Codex standard 12, Revised Codex Standard for Honey. Stan Stan Methods 11:1-8 (2002).

2 Anklam E, A review of the analytical methods to determine the geographical and botanical origin of honey. Food Chem 63:549-562 (1998).

3 Prridal A and Vorlová L, Honey and its physical parameters. Czech J Anim Sci 10:439-444 (2002).

4 Viuda-Martos $M$, Ruiz-Navajas $Y, \quad$ Fernańdez-López J and Pérez-Álvarez JA, Functional properties of honey, propolis, and royal jelly. J Food Sci 73:117-124 (2008).

5 Lay-flurrie K, Honey in wound care: effects, clinical application and patient benefit. Br J Nurs 17:32-36 (2008).

6 Lusby PE, Coombes A and Wilkinson JM, Honey: a potent agent for wound healing? J Wound Ostomy Continence Nurs 29:295-300 (2002).

7 Gallardo-Chacon JJ, Caselles M, Izquierdo-Pulido M and Rius N, Inhibitory activity of monofloral and multifloral honeys against bacterial pathogens. J Api Res 47:131-136 (2008).

8 Molan PC, Potential of honey in the treatment of wounds and burns. Am J Clin Dermatol 2:13-19 (2001).

9 Won S, Li C, Kim J and Rhee H, Immunological characterization of honey major protein and its application. Food Chem 113:1334-1338 (2009).

10 Bardy J, Slevin NJ, Mais KL and Molassiotis A, A systematic review of honey uses and its potential value within oncology care. J Clin Nurs 17:2604-2623 (2008).

11 Arvanitoyannis I and Krystallis A, An empirical examination of the determinants of honey consumption in Romania International. J Food Sci Tech 41:1164-1176 (2006).

12 Rasmussen CN, Wang X, Leung S, Andrae-Nightingale LM, Schmidt SJ and Engeseth NJ, Selection and use of honey as an antioxidant in a French salad dressing system. J Agr Food Chem 56:8650-8657 (2008).

13 Abu-Tarboush HM, Al-Kahtani HA and El-Sarrage MS, Floral-type identification and quality evaluation of some honey types. Food Chem 46:13-17 (1993)

14 Perez-Arquillue' C, Conchello $\mathrm{P}$, Arin $\sim \mathrm{O}$, Juan $\mathrm{T}$ and Herrera $\mathrm{A}$ Quality evaluation of Spanish rosemary (Rosmarinus officinalis) honey. Food Chem 51:207-210 (1994).

15 Pérez-Arquillué $C$, Conchello $P$, Ariño A, Juan $T$ and Herrera A. Physicochemical attributes and pollen spectrum of some unifloral Spanish honeys. Food Chem 54:167-172 (1995).

16 Lazaridou A, Biliaderis CG, Bacandritsos N and Sabatini AG, Composition, thermal and rheological behaviour of selected Greek honeys. J Food Eng 2004;64:9-21 (2004).

17 Meda A, Lamien CE, Millogo J, Romito M and Nacoulma OG, Physicochemical analyses of Burkina Fasan honey. Acta Vet Brno 74:147-152 (2005).

18 Naab OA, Tamame MA and Caccavari MA, Palynological and physicochemical characteristics of three unifloral honey types from central Argentina. Span J Agric Res 6:566-576 (2008).

19 Primorac L, Bubalo D, Kenjerić D, Flanjak I, Pirički AP and Mandić ML, Pollen spectrum and physicochemical characteristics of Croatian Mediterranean multifloral honeys. Dtsch Lebensm Rundsch 104:170-175 (2008).
20 Aira MJ, Horn $\mathrm{H}$ and Seijo MC, Palynological analysis of honeys from Portugal. J Api Res 37:247-254 (1998).

21 Council Regulation (EC) No 509/2006 of 20 March 2006 on agricultural products and foodstuffs as traditional specialities guaranteed (OJ L 93, 31.3.2006). This replaces Regulation (EEC) No 2082/1992.

22 The full list of products can be found at: http://ec.europa.eu/ agriculture/foodqual/quali1_en.htm [2 June 2009].

23 Andrade PB, Amaral MT, Isabel P, Carvalho JCMF, Seabra RM and Proença da Cunha A, Physicochemical attributes and pollen spectrum of Portuguese heather honeys. Food Chem 66:503-510 (1999).

24 Soler C, Gil M, García-Viguera C, and Tomás-Barberán FA, Flavonoid patterns of French honeys with different floral origin. Apidologie 26:53-60 (1995).

25 Erdtman G, The acetolysis method: a revised description. Svensk Bot Tiskr 54:561-564 (1960).

26 Association of Official Analytical Chemists, Official Methods of Analysis, 15th edition. Association of Official Analytical Chemists, AOAC, Arlington, VA (1990).

27 Bogdanov S, Martin P, Lullmann C, Borneck R, Flamini C, Morlot M, et al, Harmonised methods of the European Honey Commission. Apidologie 28:1 -59 (1997).

28 Chataway HD, Honey tables, showing the relationship between various hydrometer scales and refractive index to moisture content and weight per gallon of honey. Can Bee J 43:215-220 (1935).

29 Council of the European Union, Council Directive 2001/110/EC of 20 December 2001 relating to honey. Off J Eur Commun L10:47-52 (2002).

30 Acquarone $\mathrm{C}$, Buera $\mathrm{P}$ and Elizalde $\mathrm{B}$, Pattern of $\mathrm{pH}$ and electrical conductivity upon honey dilution as a complementary tool for discriminating geographical origin of honeys. Food Chem 101:695-703 (2007).

31 Bogdanov S, Lüllmann C, Martin P, von der Ohe W, Russmann H, Worwohl G, et al., Honey quality and International Regulatory Standards, review by the International Honey Commission. Available: http://www.beekeeping.com/articles/us/honey_quality.htm [2 June 2009].

32 Felsner ML, Cano CB, Bruns RE, Watanabe HM, Almeida-Muradian LB and Matos JR, Characterization of monofloral honeys by ash contents through a hierarchical design. J Food Compos Anal 17:737-747 (2004).

33 Kropf U, Jamnik M, Bertoncelj J and Golob T, Linear regression model of the ash mass fraction and electrical conductivity for Slovenian honey. Food Technol Biotechnol 46:335-340 (2008).

34 Popek S, Application of regression analysis as a method to determine total ash content in some selected nectar honeys. Nahrung-Food 47:36-38 (2003).

35 Terrab A, Díez MJ and Heredia FJ, Characterisation of Moroccan unifloral honeys by their physicochemical characteristics. Food Chem 79:373-379 (2002).

36 Persano-Oddo L, Baldi E and Accorti M, Diastatic activity in some unifloral honeys. Apidologie 21:17-24 (1990).

37 Persano-Oddo L and Piro R, Main European unifloral honeys: descriptive sheets. Apidologie 35:S38-S81 (2004).

38 Terrab A, Recamales AF, Hernanz D and Heredia FJ. Characterisation of Spanish thyme honeys by their physicochemical characteristics and mineral contents. Food Chem 88:537-542 (2004).

39 El-Sherbiny GA and Rizk SS, Chemical composition of both clover and cotton honey produced in A.R.E. Egypt J Food Sci 7:69-75 (1979).

40 Finola MS, Lasagno MC and Marioli JM, Microbiological and chemical characterization of honeys from central Argentina. Food Chem 100:1649-1653 (2007).

41 Nozal MJ, Bernal JL, Diego JC and Martín MT, Classifying honeys from the Soria Province of Spain via multivariate analysis. Anal Bioanal Chem 382:311-319 (2005). 